\title{
Improve the Competitiveness and Value of Rice Exports of the Mekong Delta Provinces
}

\author{
Nguyen Thi Tuong Vi, Tianjun Liu \\ College of Economics and Management, Northwest A\&F University, Yangling, China \\ Email: nguyentuvi91@gmail.com, 1tj7168168@nwsuaf.edu.cn
}

How to cite this paper: Vi, N.T.T. and Liu T.J. (2019) Improve the Competitiveness and Value of Rice Exports of the Mekong Delta Provinces. Agricultural Sciences, 10, 707-719.

https://doi.org/10.4236/as.2019.106055

Received: May 9, 2019

Accepted: May 30, 2019

Published: June 3, 2019

Copyright $\odot 2019$ by author(s) and Scientific Research Publishing Inc. This work is licensed under the Creative Commons Attribution International License (CC BY 4.0).

http://creativecommons.org/licenses/by/4.0/

(c) (i) Open Access

\begin{abstract}
Purpose: Vietnam rice has long been a product of international stature. In the commodity export of Vietnam, rice always plays as key agricultural commodities, with contributions billions of dollars each year in total export value. It not only contributes to the overall growth of the economy, but also gradually affirms Vietnam's position on the international rice market. According to General Statistics Office, in 2012, Vietnam produced 43.7 million tonnes of rice and exported record 8.047 million tonnes of rice, contributing to the total export value of $\$ 3.689$ million. However, it has not still been commensurate with the value and potential of rice from Vietnam. In addition, the fact is that in recent years, although export rice increased sharply, bringing many records for Vietnam, it had lower prices than other rice exporting countries (Thailand, India, Pakistan). So what is the cause and solution to enhance competitiveness and promote export of rice products in Viet Nam? In the increasingly complex international context, besides socio-economic development, security and national defense, food security has become a matter of international concern. The article first discusses the competitiveness, the value of rice exports and the need to improve competitiveness and export value of rice in the Mekong Delta. Then, there are some solutions proposed to improve the competitiveness and export of rice in the Mekong Delta in the coming time.
\end{abstract}

\section{Keywords}

Mekong Delta, Rice Export, Food Security, The Competitiveness

\section{Introduction}

Vietnam is located in the tropical monsoon climate with two major deltas,, the Red River Delta and the Mekong Delta. The Mekong Delta is known as the "rice 
bowl" of the whole country and the world. With an area of nearly $40,000 \mathrm{~km}^{2}$ and constantly accreted by alluvium, Mekong Delta always accounts for more than $50 \%$ of rice production and $90 \%$ of rice export of the country [1]. Therefore, the competitiveness being improved to take advantage of the export of rice will help significantly improve the farmer's life.

A long-standing paradox is that Vietnam's annual rice export output continuously sets a new record but the value of exports is not high. Part of the cause of this paradox is that rice is classified as hunter-gatherer (which is products harvested from nature without the need to spend a lot of labor gray matter) by World Trade Organization (WTO) so there is no high added value. As a result, despite the huge export volume, the value of the products is still very low. Indeed, the processing industry is still underdeveloped, the quality of rice is still very different from that of other rice exporting countries and loose links with the international community. The product-market strategy is not dynamic; legal policies and support of the State are not complete; value chain is not effective. All these have created a major barrier in raising the value of Vietnamese rice in the international arena. At present, Vietnam has acceded to the WTO and must strictly abide the provisions of this organization. Thus, we cannot change the first cause. However, the second cause is subjective and completely can be improved.

\section{Competition and Competitiveness Assessment Criteria}

\subsection{Competition}

Competition is the effort, trying to win more, the win belongs to the participant. Competition appears almost in every human activity of all ages. There is competition for development [2]. The Marxist-Leninist philosophy mentions this in the negative law of negation. According to the progression of things/phenomena, the old is no longer suitable, the new one will be born and replace the old. Competition creates the premise for the new born. Thus, competition is inevitable and takes place in every aspect of life [2].

Competition has become increasingly acute. Because of competition, the society is constantly developing. The world population is exploding, the demand for material is growing. Production and business activities increased in terms of quality and quantity. In order to create and maintain the comparative advantage, the subjects involved in economic activities must be skillful in competition and creativity. Otherwise, they will be eliminated [3]. Another difficult problem for economists who care about is the limitation of resources, including natural resources and other inputs. Economic development process has exhausted the available resources and increasing demand for artificial resources. Typically, it is technology and people. Using unwise resources, the world will soon fall into a state of crisis. This is why the economist Mankiw mentioned scarcity in the introduction of his "Principles of Economics": Resources are scarce [3]. 


\subsection{Criteria for Assessment of Competition}

Revealed Comparative Advantage ( $R C A)$ :

It is a measurement coefficient of the level of comparative advantage of this product to another product or this country to another country [2]. This coefficient represents a country's export competitiveness for a product relative to the world's export of that product.

$$
R C A=\left(X_{i} / X_{j}\right):\left(X_{i w} / X_{w}\right)
$$

In which:

$X_{i j}$ : Export turnover of product “ $i$ " of the country “" $j$.

$X_{j}$ : Total export turnover of country “ $"$ ".

$X_{i w^{*}}$ : Export turnover of product " $i$ " of the world.

$X_{\mathrm{w}}$ : Total export turnover of the world.

If:

$R C A>2.5:$ The product has a very high comparative advantage.

$1<R C A<2.5$ : Product has comparative advantage.

$R C A<1$ : The product has no comparative advantage.

Market share

Market share reflects consumption market of the product that obtained of a country or a particular business. If a product only works narrowly in a region of a country's local area, Market share of business owners of this product is not large. Products with small market share are mostly small-scale domestic products [3]. In return, there are products that exist across borders, consumers can easily find them everywhere. This is a product characteristic of transnational companies.

Price

The price reflects the willingness of the consumer to get the desired product. Price is also an important criterion in determining the competitiveness of a product [3]. With relatively equivalent features, the price of one branded product is cheaper, it will have comparative advantage over other brands.

\section{The Necessity to Improve the Competitiveness and Value of Rice Exports of the Mekong Delta Provinces}

\subsection{Overview of Vietnam Mekong River Delta}

\section{Characteristics}

Geographic location [4]: The Mekong Delta is located as a peninsula with three sides in the East, South and South-West, bordered by the sea (has a coastline of $700 \mathrm{~km}$ ), the border with Cambodia on the west and the southeastern economic region in the north-Vietnam's largest economic region. The Mekong Delta is located on relatively flat terrain, the canal and river network are very thick, which are very convenient for transportation in the country.

Geographic coordinate: The Mekong Delta (Mekong Delta) is located in the southernmost part of Vietnam (the Southwest region) with the Northeast 
bounded by Ho Chi Minh City, the east and the South by the East Sea, north by Cambodia, the west borders the East Sea and the Gulf of Thailand.

The natural area of the region is 40,548.2 kilometer squares (about 4 million ha), equaling $12 \%$ of the whole country; of which about $65 \%$ of the land is used for agriculture and aquaculture [4].

There are 2.6 million hectares in the Mekong River Delta used for agriculture production, less than $30 \%$ of the country's total but it contributes more than $50 \%$ of Vietnam's total output; in 2011, the rice output was 24,226,600 tons [5]. Due to its mostly flat terrain, almost $60 \%$ of the region's land can be used for agriculture and most of the agriculture land is used for rice cultivation. Kien Giang province, An Giang province, and Dong Thap province are the best three producers within the region.

Population [4]: The 2016 population of the region reached over 17,478 million people, equaling $21 \%$ of the national population, with an average population density of 407 persons per $\mathrm{km}^{2}$ (compared to 233 persons per $\mathrm{km}^{2}$ in the whole country); the proportion of women accounted for $51.2 \%$, the proportion of the population living in urban areas is $17.1 \%$. According to the statistics on employment and employment, the population of working age in the frist (I) sector occupies $60.13 \%$, region II accounts for $13.11 \%$ and the third sector accounts for $26.76 \%$. Poor households account for about $15 \%$. Literacy rate: $88 \%$. Life expectancy is 3971.1 years. In the community of nations., Kinh majority accounts for more than $90 \%$, followed by Khmer, Hoa and Cham with $8 \%$ [5].

The Mekong Delta has 13 administrative units, including one centrally governed city (Can Tho city) and twelve provinces (Long An, Dong Thap, An Giang, Tien Giang, Ben Tre, Vinh Long, Tra Vinh, Hau Giang, Kien Giang, Bac Lieu, Soc Trang and Ca Mau) (Figure 1).

\section{PCI Regional Competitiveness Index of 2016}

The Provincial Competitiveness Index (PCI) is the rating of Vietnam's provincial governments in building a business environment conducive to the development of private enterprises. This is a collaborative research project between the Vietnam Chamber of Commerce \& Industry and Vietnam Competitiveness Enhancement Project (USAID-funded project). This indicator was first published in 2005 in 47 provinces [6]. From the second, all 64 provinces were included in the ranking and component indicators are also enhanced.

Criteria for inclusion in the ranking are: the cost of entry to the market, access to land and stability in land use, ensure transparency and access to information, cost of time to implement the regulations of the State, unofficial expense, preferential treatment for State-owned enterprises, dynamism and pioneering of provincial government, private economic development policy, labor training, legal institutions.

In general, from Figure 2, we can see the area in the Mekong Delta is considered to be quite high, ranked 3rd in 6 domestic areas (behind the Red River Delta and the Central Coast). This is an opportunity for the region to attract 


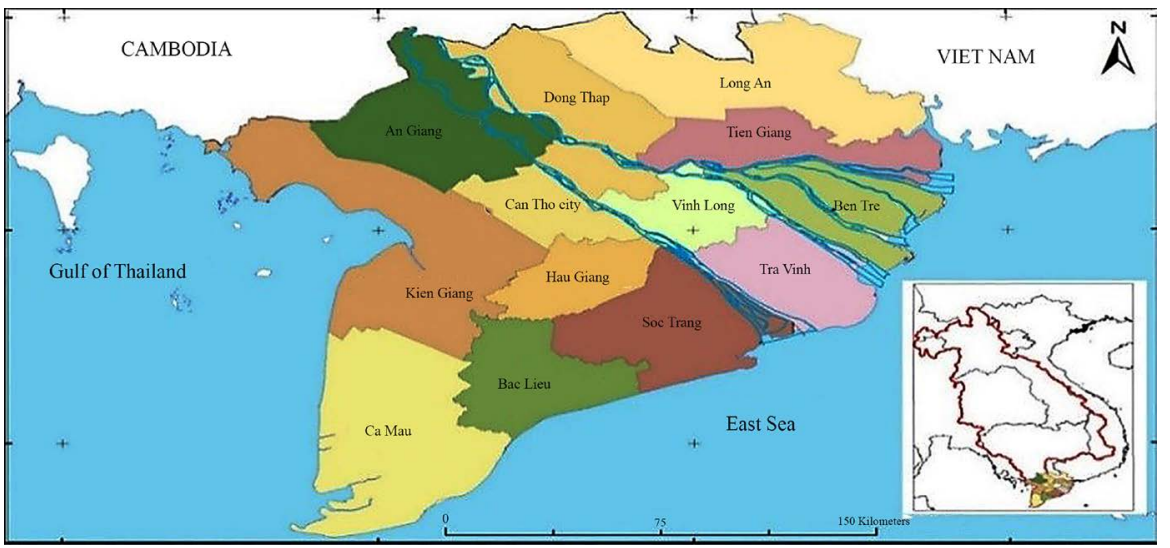

Figure 1. Vietnam Mekong River Delta [4].

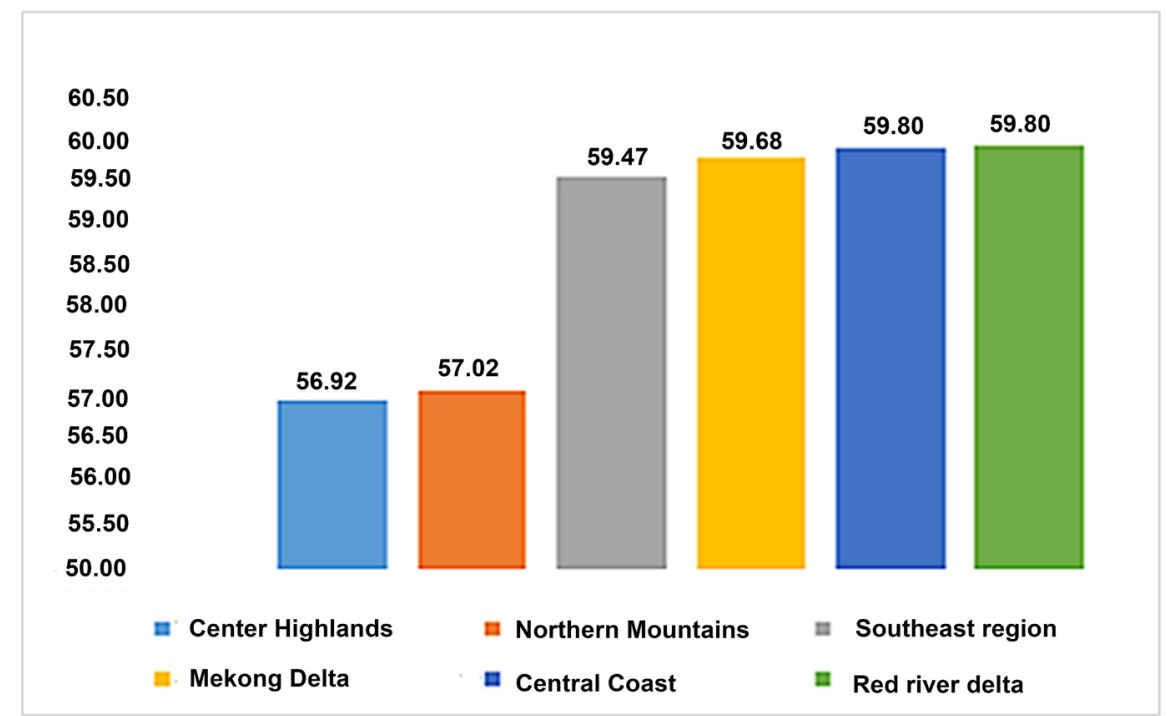

Figure 2. Average PCI index of the regions (Source: VCCI) [6].

investment and from that can develop stronger infrastructure for the region, contributing to enhancing regional competitiveness.

However [6], PCI-provincial competitiveness index is uneven among provinces in the region, of which, the province with the highest PCI was Dong Thap with 64.96 (very good) and Ca Mau with 56.36 (average) as shown in Figure 3. This imbalance hindered the synchronous development of the region.

\subsection{Overview of rice Export Situation in the Mekong Delta}

The Mekong Delta has an excess of paddy rice production compared to its consumption of $9-12$ million tons. Vietnam's rice exports are mainly derived from rice produced in the Mekong Delta, the remaining surplus will be transferred to other food shortages area by roads, railways and waterways.

However, due to the national food security and food aid policy of the government, the government restricts the annual food exports from 6 to 7 million tons due to natural disasters, epidemics that cause crop failure [5]. 


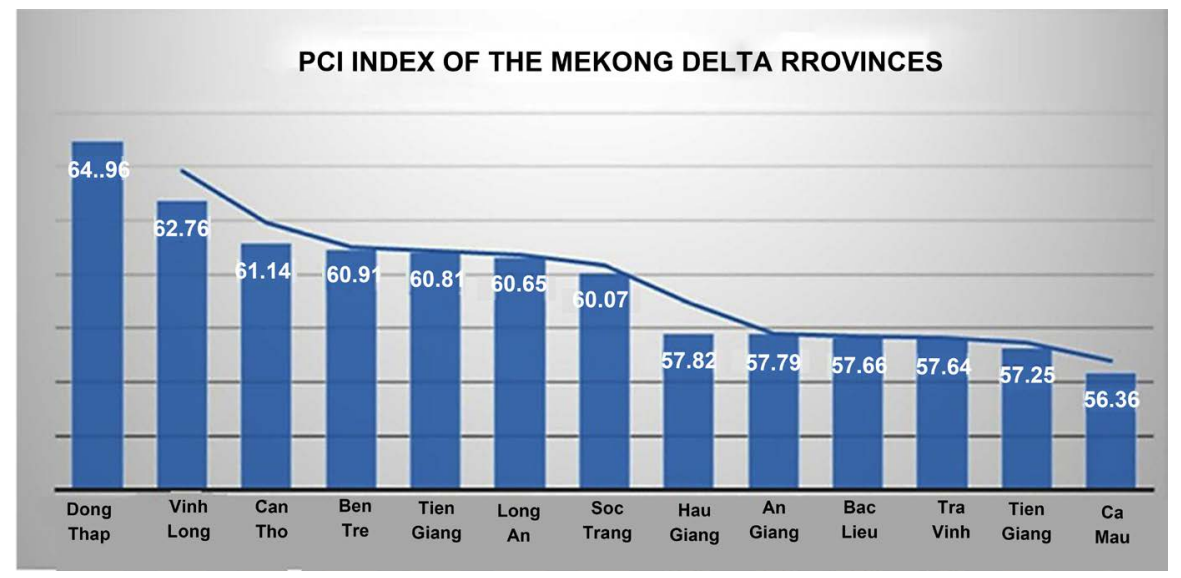

Figure 3. PCI index of the provinces in the region in 2016 (Source: VCCI).

Especially, a few years ago, the fishery sector of Pangasius fish exports in the area was developed strongly and highly effective [7], so a large portion of the area of rice that has been converted to freshwater aquaculture has affected paddy production due to the area of rice production is in danger of reducing. It is contributing to the use of seeds and arranging suitable cultivation seasons for rice production in Mekong River delta.

\section{Production situation}

The Mekong Delta is one of the largest rice producing regions in the country, contributing more than $50 \%$ of annual rice production and over $90 \%$ of total rice exports [8]. At present and in the long run, the rice plant remains the staple crop of the Mekong Delta because the rice plant is a traditional crop, suitable to the natural and socio-economic conditions of the region and the food security policy of Vietnam [9]. However, the outbreak and the change in the toxicity of many pests have had a significant impact on rice production in the Mekong Delta. By regularly researching and evaluating the adaptability of new rice varieties in the Mekong Delta's eco-regions of The Mekong Delta Rice Research Institute.

\section{Productivity, output, cultivation area}

[5] Rice productivity and output have increased continuously in the past 25 years. Specifically, paddy average yield increased by 3.25 percent per year from 3.18 tonnes per hectare in 1990 to 5.77 tonnes per hectare in 2015. At the same time, the area under cultivation in the past 25 years has increased by $26.8 \%$ and has resulted in a dramatic increase in rice output from 19.225 million tons in 1990 to 45.22 million tons in 2015 with an average growth rate of $5.41 \%$ [5] (Figure 4). Thus, productivity is a major factor in increasing paddy yields over time.

Besides the above positive aspects, according to the data over the past years, it has also been found that productivity growth rates tend to decrease over time. In the period of 2011-2015, the growth rate is the lowest with an average of only $1.04 \%$ [5]. With the difficulty to increase the area of cultivation, the speed of productivity growth has dropped sharply and it will drastically reduce rice 


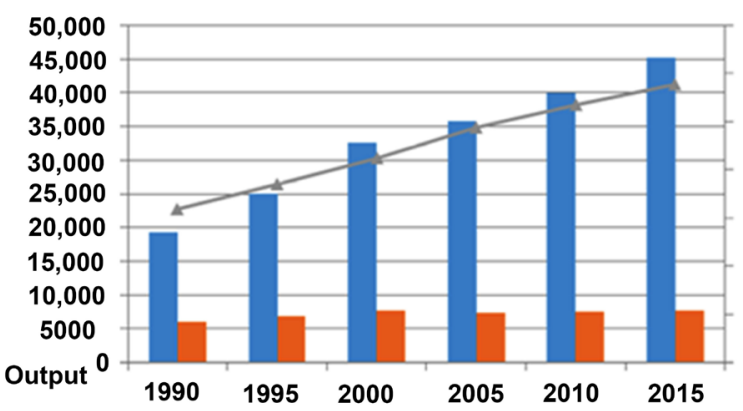

Producitivity

Figure 4. Output, productivity and area of rice cultivation in Vietnam [5] (Source: General Statistics Office).

output in the coming years. It may even be impaired by the climate change that is affecting the cultivated area.

With $90 \%$ of Vietnam's rice exports are from the Mekong Delta, comparing the Mekong Delta rice yield with some Asian countries, rice yields in the Mekong Delta are relatively high compared to other countries (only lower than the productivity of China and Japan) and productivity is still increasing. This is a significant advantage in reducing production costs.

The yellow line on the above table shows that the comparative level of Mekong Delta rice productivity (the average yield for rice of the Mekong Delta is 6.03 ton/ha) is quite high compared to the major exporting countries like India and Thailand and Pakistan (has been described in Figure 5). However, rice production in the Mekong Delta is usually on a small scale, focused on arbitrary production, spontaneous production of farmers such as: sowing too much seed and thick, abuse of spraying plant protection drugs, chemical fertilizer and incorrect use of the process [9], ... These have been causing difficulties and obstacles to disease prevention.

In addition, shortage of breeding is a matter of concern. Restrictions on the purity of varieties have reduced quality and productivity. Although there are seed sources provided from universities and research institutes but the quantity is not much.

Increasing the cultivation area in the case of the country is also difficult due to land constraints as well as the problem of converting some crops to other crops that have higher economic value. The increase of the area by increasing the crop will have negative effects such as increased costs, disease situation... At present, the area cultivated by rice cultivation is over 3 million hectares, but the cultivated area is about 7 million hectares per year, this means that one year we plant more than two crops, this shows that the possibility of increasing the crop is very difficult [1]. Meanwhile, Thailand has many opportunities to increase rice production due to its potential to increase productivity as well as conditions to expand the area grown by crop.

\section{Rice export context of Mekong Delta provinces}

During the period of 1989-2015, rice export was the main export item of the country and the Mekong Delta provinces. Every year, Vietnam's rice exports 


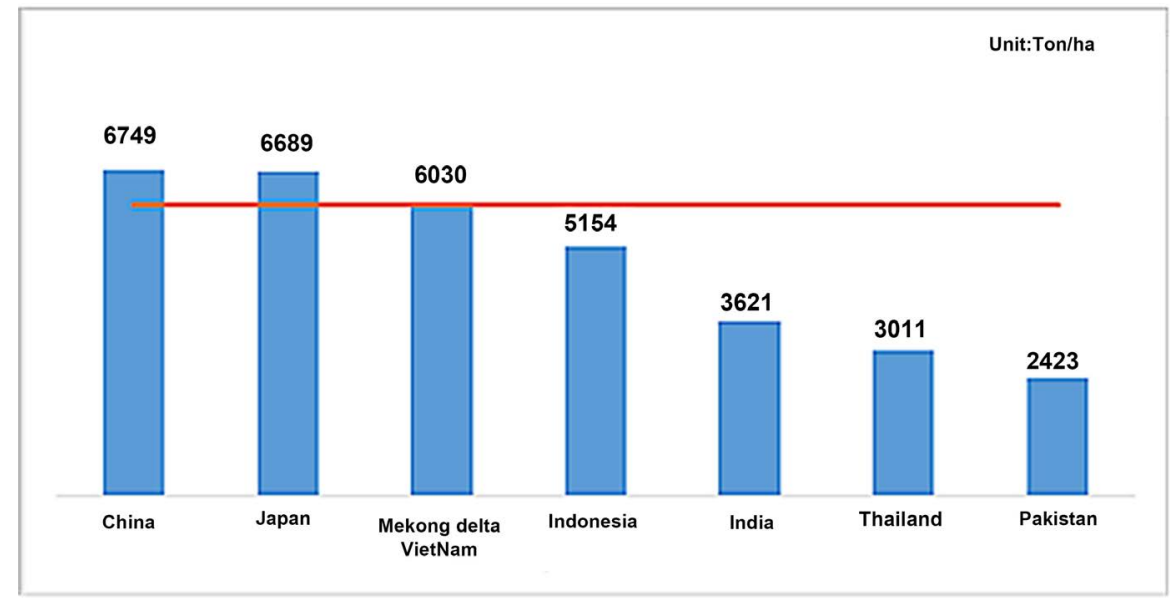

Figure 5. Rice productivity of some countries compared to the Mekong Delta [10]. (Source: FAOSTAT, 2016) [10].

account for $13 \%$ to $15 \%$ of total rice exports worldwide [5]. In particular, Mekong Delta mainly supplies rice for export. According to statistics, rice export accounted for approximately $4 \%$ of total export turnover of the country. Rice export has become a major source of foreign currency revenue of Mekong Delta provinces.

However, in recent years, rice export of Vietnam is not stable both in output and export turnover. For example, in 2005, export output of rice were 5.3 million tons, but only 4.5 million tons in 2007. In 2012, rice exports reached a record of 8.047 million tons, earning US $\$ 3.5$ billion [1], but export turnover decreased compared with 3.4 billion dollars in 2011 [7]. Moreover, the whole country's rice export volume in 2016 only reached 4.9 million tons, the turnover was estimated at US $\$ 2$ billion, down $26 \%$ in volume and $22 \%$ in value over the same period in 2015. Vietnam's rice export in 2016 has dropped a record in nearly 10 years (as shown in Table 1). This is the lowest level from 2009 to now. The export value does not reflect the export output, showing that rice exports of Vietnam in general and Mekong Delta in particular are facing fierce competition with rice exporters in the region and in the world.

\section{Structure of Vietnam's rice export market}

Looking at Table 2 we can see that the main export market of Vietnam mainly focuses on Asian countries-the most populous region in the world and the main food is rice. Besides, Vietnam has expanded its rice consumption market to some African countries, Latin America and the Middle East [5]. The trend of new market structure has helped the Mekong Delta rice products gradually appear around the world.

[9] Each country exporting rice often has its own major export markets and competes in other export markets. This may stem from rice taste, migrant community, cultural similarity of rice consuming countries with rice exporting countries. Indian rice is often exported to Africa (Nigeria, Senegal, Cote d'Ivoire, Benin) and Arab, Muslim countries (Saudi Arabia, UAE, Indonesia). While 
Table 1. Rice export volume of Vietnam and Mekong Delta in the period of 2011-2016.

\begin{tabular}{ccc}
\hline \multirow{2}{*}{ Year } & \multicolumn{2}{c}{ Export output (million tons) } \\
\cline { 2 - 3 } & Mekong Delta & The whole country \\
\hline 2011 & 6.1 & 7.1 \\
2012 & 7.21 & 8.05 \\
2013 & 5.14 & 6.68 \\
2014 & 5.85 & 6.38 \\
2015 & 6.2 & 6.58 \\
2016 & 4,78 & 4.9 \\
\hline
\end{tabular}

(Source: General Statistics Office).

Table 2. Structure of Vietnam's rice export market [5].

\begin{tabular}{cccccc}
\hline Year & Asia (\%) & America (\%) & (\%) Africa & Europe (\%) & Other (\%) \\
\hline 2013 & 59.78 & 6.78 & 28.18 & 3.63 & 1.63 \\
2014 & 67.22 & 8.78 & 19.27 & 2.95 & 1.87 \\
2015 & 72.91 & 11.23 & 11.7 & 3.12 & 1.04 \\
\hline
\end{tabular}

(Source: Summary from the General Statistics Office).

Pakistan's rice is strongly directed to the Middle East, Northern Europe, North America, and some other Asian countries (China, Bangladesh). And US rice is consumed mainly in Latin American countries, Japan, Canada. Vietnam and Thailand are two major exporters to Asia (China, ASEAN) and Africa (South Africa, Cote d'Ivoire). Thailand is also able to penetrate rice markets of developed countries such as Japan, the US, Canada, etc. Meanwhile, Vietnam can export rice to EU countries [11].

\section{Rice export prices}

For many years, Vietnam's rice exports have always been the leading position in the world. The Mekong Delta provides almost all of the exported rice [8]. The amount of foreign currency earned from rice exports has partly helped the country stand firm against the difficulties and challenges of the world economic crisis. Vietnamese rice prices are affected by fluctuations in world rice prices [8].

Observing Figure 6, rice prices only increased slightly in 2012, then rice prices tended to decrease year by year, compared with 2011, the price of rice exported by Mekong Delta in 2015 decreased by 20.4\%, equivalent to 90 USD/ton [11]. The rice export market is quite fierce, the demand for imports from the markets is low, while the high and unfavorable inventory of the financial situation... has impacted the price of export rice of the world tend to decrease. In particular, in Asia rice prices continued to decline and at a time hit the lowest level in recent years. And Vietnam's rice export price is no exception. However, compared to the world price, in the period of 2011-2015, Vietnam's rice export price is always much lower than the world price, the average price difference is from $35-135$ 


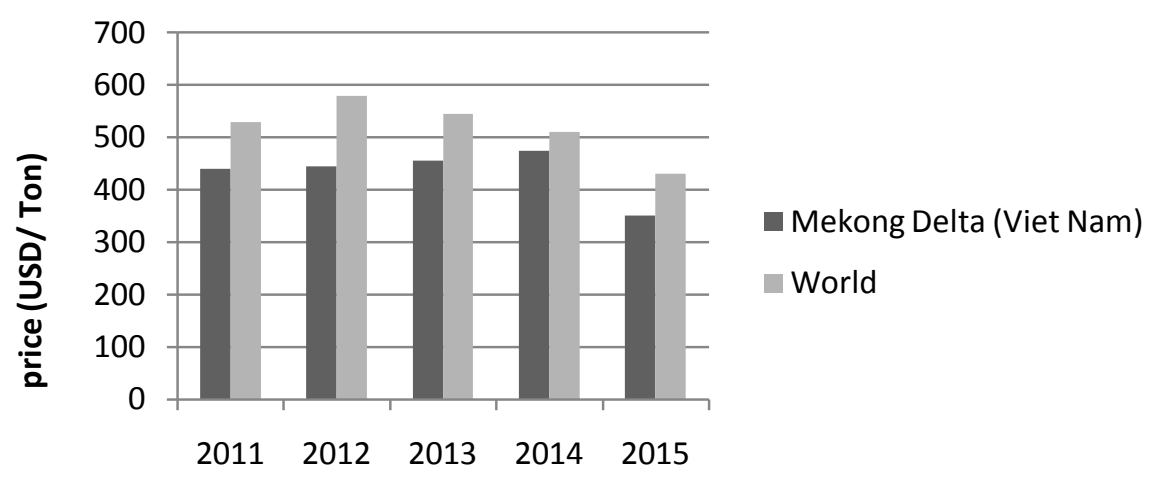

Figure 6. The average export price of rice in the world and the Mekong Delta. (Source: Trade map, International Trade Center).

USD/ton [11]. The main reason is still in the two words of quality, Vietnamese rice varieties are not applied to meet the high nutritional composition of the world rice. In addition, rice production process of Vietnam is still manual.

\section{Market share and comparative advantage coefficients $R C A$}

Since 2011, Vietnam's rice market share has decreased slightly (in Table 3). This is an unfortunate expression for Vietnamese rice exports. In recent years, in addition to Thailand, the rise of India has contributed to enriching the list of Vietnam's competitors. In order to maintain its position on the international rice market, Vietnam needs to further improve its competitiveness.

From the formula for calculating the expression of comparative advantage factor (RCA) presented above, we have RCA coefficient as Table 4.

RCA coefficient of Vietnamese rice in recent years is always greater than 2.5 many times. It means that Vietnam's rice products are highly competitive. This is very consistent with the fact that rice is among the top 8 items (rice, coffee, tea, cashew, seafood, rubber, textiles and leather shoes) with the highest competitiveness in country [7]. In order to maintain the competitiveness of this item and expand the market share of rice exports in the world, Vietnam needs to focus on product development, rice quality management, enhance the supporting industries and develop policies to promote products, formulate appropriate strategies to help the rice brand in the Mekong Delta region can penetrate into more advanced markets.

\section{Some Solutions to Improve the Competitiveness of Rice Export Value of the Mekong Delta Provinces}

Mekong Delta is the largest rice supplier in the country, helping Vietnam to export rice to the third in the world. But Vietnam's rice production still has many shortcomings. The fact that rice farmers in the region mainly rely on their accumulated experience, sometimes these farming practices lack scientific [12]. Enterprises seeking export rice must go through intermediaries; The association with import partners is also found by enterprises. Policies of the State support have not really brought about high efficiency. Research works have not yet been 
Table 3. Market share of Vietnamese rice in the rice export market in the 2011-2015 period.

\begin{tabular}{cccccc}
\hline Year & 2011 & 2012 & 2013 & 2014 & 2015 \\
\hline Market share (\%) & 21.92 & 21.81 & 22.05 & 22.46 & 21.23 \\
\hline
\end{tabular}

Table 4. RCA coefficient of rice in Vietnam in the period of 2011-2015.

\begin{tabular}{cccccc}
\hline Year & 2011 & 2012 & 2013 & 2014 & 2015 \\
\hline RCA & 49.71 & 50.03 & 49.37 & 51.28 & 48.91 \\
\hline
\end{tabular}

applied in practice. In order to improve the competitiveness and value of the region's rice exports, there must be close links between farmers, businesses, scientists and the state.

Links between businesses and farmers. Enterprises need to enhance direct contact and capital support for farmers through credit guarantees, preferential loans, building a rice processing facility and purchasing agricultural insurance in full to minimize losses due to unfavorable weather conditions or outbreaks of diseases for farmers [12]. Farmers must be responsible for providing businesses with the right quality and quantity, as well as ensuring the right processes and farming techniques agreed with the enterprise. Thus, the supply of rice for production and export will ensure the quantity and quality of products. Rice farmers will be able to stabilize their output at a reasonable price, not afraid of price pressures, rest assured to cultivate the next crop.

Links between scientists and farmers. Seed quality will determine the level and value of the product. Research data to create new varieties of rice for high productivity and quality of scientists will not be complete and accurate without information and experience from farmers [13]. Similarly, this close link also facilitates the testing and feedback process.

Links between businesses and scientists. In this connection, businesses play the role of investors and sponsors, invest costs to order research centers, scientific institutes and universities to carry out research projects on breeding new rice varieties, soil improvement measures as well as improvements in farming techniques, harvesting, processing and preserving rice products... [14] At the same time, businesses also act as a bridge to facilitate scientists to approach rice-growing households who have signed contracts with businesses to implement, thereby proposing high feasibility solutions and timely adjustment of problems arising in new seed applications. In addition, enterprises need to link and adopt functional agencies related to rice production and export activities to grasp and provide timely information to scientists in order to prioritize the selection of quality varieties that meet the requirements of the import market (9).

The role of the State. The state will play a leading role, observing and intervening in time to keep the links closely developed. Setting up inspection centers, regularly supervising and inspecting production activities and rice quality to 
grasp the production situation and ensure the quality of rice production [13]. Post on information in the mass media, organize local activities or distribute free publications about new varieties, new method of cultivating, or eliminate pests and diseases for farmers so that they can produce in accordance with market demands or in line with the national agricultural development strategy. At the macro level, the State strengthens cooperation and connective with foreign countries and economic regions to find new markets and partners [14]. Simplify customs procedures and have policies to create favorable conditions for businesses to boost rice export activities to foreign markets. When businesses expand trade and gain more profits, they will actively promote their link with scientists and farmers.

\section{Conclusion}

Rice exports are one of the foreign trade activities that generate a great source of income for the country and the Mekong Delta provinces, making an important contribution to improving the lives of rice farmers in this place. Vietnam is a major rice exporter in the world, but the export value from this activity is not commensurate with the current position of Vietnam. Part of the reason is that the competitiveness and quality of Vietnam's rice are still low compared to other major rice exporting countries. In order to improve this issue, there must be a coordinated and close relationship between farmers, businesses, scientists and the state. The context of Vietnam is aiming at industrialization and modernization, high and urgent capital needs. Enhancing competitiveness and export value of rice will be a significant contribution to the process of national renewal.

\section{Conflicts of Interest}

The authors declare no conflicts of interest regarding the publication of this paper.

\section{References}

[1] Linh, T. (2013) Rice Export in 2012 Reached a Record. VTV Online. http://vtv.vn/Kinh-te/Xuat-khau-gao-nam-2012-dat-ky-luc/53937.vtv

[2] Porter, M.E. (2004) Comparative Advantage: Creating and Sustaining Superior Performance. The Free Press, New York, 565-580.

[3] Mankiw, N.G. (2001) Principles of Economics. Harcourt College, San Diego, CA.

[4] International Centre for Environment Management. http://icem.com.au/

[5] General Statistics Office. http://www.gso.gov.vn/default.aspx?Tabid=217

[6] Vietnam Chamber of Commerce and Industry. https://vcci-hcm.org.vn/

[7] Vietnam Food Association (2014) Rice Export Results to December 31, 2011.

[8] Huynh, T.N. and La, H.L. (2015) Internal Factors Affecting the Competitiveness of Private Enterprises in Can Tho City. Scientific Journal of Can Tho University, No. 36, 72-80.

[9] Mai, V.N. (2013) Situation and Factors Affecting the Competitiveness of Small and 
Medium Enterprises in Dong Thap. Scientific Journal of Can Tho University, No. 27, 45-53.

[10] FAOSTAT—Food and Agriculture Data. http://www.fao.org/faostat/en/\#home

[11] International Trade Center, Trade Map. http://www.trademap.org

[12] Nguyen, T.B.M. (2015) Some Solutions to Improve the Efficiency of Import and Export of Agro-Forestry and Fishery Products. Journal of Finance, No. 9, 50-52.

[13] Phan, Q.V. (2015) Solutions to Increase Rice Export Competitiveness in Vietnam. Asia-Pacific Economic Journal, No. 10, 41-43.

[14] Pham, T.T.H. and Pham, H.P. (2014) Solutions for Enhancing Capacity in Rice Export in Vietnam. Scientific Journal of An Giang University, 3, 52-57. 